\title{
FROM LAND REFORM TO POO PROTESTING: \\ SOME THEOLOGICAL REFLECTIONS \\ ON THE ECOLOGICAL REPERCUSSIONS \\ OF ECONOMIC INEQUALITY
}

\author{
Ernst Conradie \\ Religion and Theology \\ University of the Western Cape
}

\begin{abstract}
This article consists of three distinct parts. The first part offers a number of observations on land as a lens to interpret economic inequalities in South Africa. The second part extrapolates such observations to explore the ecological dimensions of urban land reform with specific reference to the ongoing service delivery protests over sanitation (dubbed 'poo protesting') as reported in the media and more specifically in the Cape Times. The third part offers some theological and ethical reflections on the human need for sanitation as a form of internal critique of the engagement with such service delivery protests by the so-called 'Concerned Citizens Group' in which the author was involved.
\end{abstract}

Key Words: Docetism; Ecology; Land Reform; Poo Protests; Sanitation

\section{Introduction}

In the second semester of 2013, I presented a postgraduate module in Ethics at the University of the Western Cape together with Professor Charles Amjad-Ali on the theme of "Land as a lens to interpret economic inequalities in South Africa". We read together a number of books on the themes of land reform and economic inequality. In this contribution I will first offer a number of observations emerging from our limited engagement with such literature (as indicated in the references). I will then extrapolate such observations to explore the ecological dimensions of urban land reform with specific reference to the ongoing service delivery protests over sanitation (dubbed 'poo protesting') as reported in the media and more specifically the Cape Times (with the obvious limitations that this implies). ${ }^{1}$ Given such observations, I will then offer some theological and ethical reflections on the human need for sanitation as a form of internal critique of the engagement with such service delivery protests by the so-called 'Concerned Citizens Group' in which I was involved.

\section{Observations on Land Reform and Economic Inequality}

1. Land reform in South Africa after 1994 has three distinct components, ${ }^{2}$ namely land restitution by settling land claims following injustices since the proclamation of the

Since there are developments regarding service delivery protests over sanitation almost on a daily basis, this contribution can only account for a limited period, namely up to the end of March 2014.

2 This distinction between land restitution, land redistribution and tenure reform (requiring a three-pronged approach) 
Natives Land Act on 20 June 1913; land redistribution in order to address inequalities following centuries of Portuguese, Dutch and British imperialism and colonialism; and tenure reform in order to develop systems of ownership that will protect the rights of individuals and emphasise the responsibility of all for the common good. ${ }^{3}$

2. There is consensus over the historical significance of the Natives Land Act of 1913 for understanding contemporary economic inequalities. ${ }^{4}$ The land acts of 1913 and 1936 did not create dispossession by themselves but legitimised the colonial conquest of land. At first $7 \%$ and later $13 \%$ of land was reserved for blacks. This was consolidated by forced removals in the $1950 \mathrm{~s}$ and $1960 \mathrm{~s}$ when 3.5 million people were relocated. This set parameters for the distribution of land ownership in the form of commercial agriculture, urban land and mining rights. However, the immediate impact of the Natives Land Act had more to do with land use than with land ownership. It outlawed share cropping agreements so that share croppers had to sell their labour on commercial farms, find employment in towns and urban areas (especially in the mining sector) or move to the so-called reserves. This polarised society on the basis of race in a way that cannot easily be reversed. The early impact of these developments was graphically narrated by Sol Plaatje. Interestingly, he also commented on the plight of domesticated animals in the aftermath of the proclamation of the Act. ${ }^{5}$

3. The introduction of the Natives Land Act of 1913 may be regarded as a function of the political compromise through which the Union of South Africa was established in 1910. This was based on the policy of segregation followed throughout the British Empire supposedly to allow for indigenous self-governance within an economic commonwealth of nations, but in effect based on the assumption that the assimilation of indigenous population through Western education is not feasible for the whole population. Apartheid in South Africa represents a particularly crude phase in which this policy of segregation (of divide and rule) was radicalised. Post-apartheid South Africa presents a departure from this policy through an inclusive democracy that seeks to extend good quality education, development and the production of wealth to the whole population. However, the structures for providing education (based on fee structures and proximity of schools), health services (aligned with medical aid schemes) and municipal services (racial divisions on the basis of town planning cannot be overcome easily) still remain deeply segregated, especially in terms of class. Since the South African constitution protects property rights against expropriation, the racialised inequalities in (rural) land ownership have not been overcome and remain highly contested. ${ }^{6}$

is found for example in Cherryl Walker's study, Land-marked: Land Claims and Land Restitution in South Africa (Johannesburg: Jacana, 2008:199).

3 Tenure reform is not discussed in this contribution, given the focus on urban land even though the ownership of land in informal settlements is also contested. For a powerful challenge to the reinforcement of Bantustan boundaries through Lawson's traditional leadership, see Aninka Claassens' article, "Tribal elite makes joke of land reform", Cape Times 9 April 2013:9.

4 See, for example, Lungisile Ntsebeza \& Ruth Hall, The Land Question in South Africa. Cape Town: HSRC Press, 2007.

5 See Sol Plaatje, Native Life in South Africa (Northlands: Picador Africa, 2007). He says: “... for sheep has no choice in the selection of a colour for their owners ... so why should they be starved on account of the colour of their owners? We knew of a law to prevent cruelty to animals, but had never thought that we should live to meet in one day so many dumb creatures making silent appeals to heaven for protection against the law" (p. 80).

6 One survey asked respondents whether they agreed or disagreed with the statement, "Most land in South Africa was taken unfairly by white settlers, and therefore they have no right to the land today." Only 8 per cent of white 
4. The ecological impact of the Natives Land Act of 1913 within the larger context of colonialism and apartheid is well documented in the literature. ${ }^{7}$ Let me mention four aspects. Firstly, a colonial mind-set does allow for nature conservation so that South Africa may rightly pride itself over its famous national parks, although these were (due to separate amenities) and still are (due to fee structures and geographic distance) easily accessible to a (white) elite only, while the indigenous population was often evicted from such land. Secondly, the degradation of commercial farm land for example as a result of inappropriate forms of mechanisation (to save labour costs) and the use of fertilisers and pesticides is well documented - despite and illustrated precisely by experiments with organic farming. Thirdly, land-distribution together with forced removals led to localised forms of over-population in the 'reserves' and later the 'homelands'. The population density in rural areas at times exceeded that of urban areas. This had a destructive impact in terms of deforestation and overgrazing, leading to massive soil erosion, the depletion of land and prospects for sustainable agriculture. Fourthly, influx control through pass laws implied that urban infrastructure was not developed according to the pace of urbanisation. This led to the proliferation of informal settlements and the current massive back-log of housing. ${ }^{8}$ One may therefore observe that the ecological impact of land use is also if not primarily visible in urban areas. In fact, one may argue that many of the problems experienced by the poor in South Africa on a daily basis are of an ecological nature if not always recognised as such. ${ }^{9}$ Consider the role of local forms of over-population, political conflict over scarce resources, waste removal, flooding and water-borne diseases, noise pollution in neighbourhoods close to highways and airports, air pollution and the associated lung diseases. Admittedly, problems related to unemployment, education and corruption have only an indirect ecological dimension. More recently, the urban dimension of land reform prompted social unrest over service delivery and especially over sanitation. I will return to that below.

5. Due to the narrative of land dispossession, land reform constitutes a crucial dimension of the transition towards a post-apartheid society, especially by settling land claims and rural land redistribution. However, this significance often appears to be mainly of a symbolic nature due to several problems that plague rural land reform. These include administrative problems to resolve land claims, the development of infrastructure on such land by new owners, the relatively low number of people affected by settlements thus far and the reality that many land claims are settled through financial compensation and not land ownership. In addition, those affected by land dispossession in the past and their descendants have experienced demographic changes that alter their relationship to

respondents agreed, in contrast with 85 per cent of blacks. See Fred Hendricks" essay, "Rhetoric and reality in restitution and redistribution: Ongoing land and agrarian questions in South Africa", in Fred Hendricks, Lungisile Ntsebeza and Kirk Helliker, The Promise of Land: Undoing a Century of Dispossession in South Africa.

Johannesburg: Jacana, 2013:35.

7 See, for example, Jacklyn Cock \& Eddie Koch (eds.), Going Green: People, Politics and the Environment in South Africa (Cape Town: Oxford University Press, 1991); Alan Durning, "Apartheid's environmental toll” Worldwatch Paper 95 (1990), Washington, DC: Worldwatch Institute; and Mamphele Ramphele and Chris McDowell (eds.), Restoring the Land: Environment and Change in Post-apartheid South Africa. London: Panos, 1991.

8 According to the National Development Plan there is a national back-log of 2.1 million housing units that will cost 300 billion to address.

9 This was already argued by L Lawson in an essay entitled "The ghetto and the greenbelt" (1991), in Cock \& Koch (eds.) Going Green, 46-63. 
the land. ${ }^{10}$ Moreover, land redistribution is inhibited by the willing buyer principle employed, the need for infrastructure, farming skills, financial resources and administrative skills to sustain such land reform in the long run. There is a difference between meeting national targets for black land ownership (the politics of elite redistribution through black economic empowerment) and poverty reduction through improved rural livelihoods. ${ }^{11}$ It must also be recognised that a large proportion of land claims relate to urban land so that the warning of a misplaced agrarianisation should be heeded. ${ }^{12}$ For that reason statistics on total land redistribution require interpretation: the number of hectares transferred needs to be balanced against the market value of such land, the small percentage of arable land in South Africa (only 13.5\%) and the number of people whose livelihood may be affected. ${ }^{13}$ There are therefore limits to what land redistribution can achieve to overcome economic inequalities, also given the constitutional protection of property rights (which remains a contested aspect of the constitution).

6. Even if rural land ownership would roughly reflect current demographic patterns as a result of land redistribution or expropriation, this would not undo the impact of the Natives Land Act of 1913. It will not and cannot overcome current economic inequalities for at least five reasons:

- Firstly, the shape of the current economy is vastly different compared to a century ago in the sense that agriculture forms a much smaller proportion of GDP. Various forms of services outweigh agriculture, mining and industry together.

- Secondly the value of land compared to the size of the economy is vastly different as a result of the transfer of capital to other instruments, including shares in various companies. A redistribution of wealth in terms of land ownership will not by itself address economic inequalities since most of the wealth generated historically through land use is no longer invested in agricultural land. ${ }^{14}$

- Thirdly, the accumulation of capital should be factored in in terms of the loss of educational and employment opportunities on the one hand and the systematic way in which apartheid allowed for 'legalised' self-enrichment on the other. How to deal with the beneficiaries of apartheid remains a fundamental cultural problem - which is aggravated by the emergence of a new black elite on the basis of black economic empowerment.

- Fourthly, the patterns of migration and especially urbanisation imply that if land reform is to address current economic inequalities, it would need to include an urban focus. The land crisis in urban areas is deeply connected to that in rural areas, the source of such migration. While the desperate plight of the rural poor may be partially addressed through a transfer of land ownership, this will not by itself address urban poverty even though the lack of housing forms an important

10 For a detailed discussion of such difficulties, see Walker's study entitled Land-marked: Land Claims and Land Restitution in South Africa. She observes that the 'master narrative' of dispossession that can be reversed through restoration is too simplistic since it does not take social change and environmental constraints into account. For a critique of Walker's position, see Fred Hendricks' essay, "Rhetoric and reality in restitution and redistribution: Ongoing land and agrarian questions in South Africa", in Hendricks, Ntsebeza and Helliker, The Promise of Land, p. 27-53.

11 See Walker, Land-marked, p. 202.

12 See Walker, Land-marked, p. 226.

13 See Walker, Land-marked, p. 198-229.

14 See Walker, Land-marked, p. 43. 
dimension of urban poverty. There is in any case multiple links between urban and rural poverty, intersecting with each other through migrant and seasonal labour.

- Finally, the altered shape of the economy (from agriculture to mining to industry to services) has led to a dramatic shift in employment patterns. ${ }^{15}$ There was a demand for cheap unskilled labour in 1913, so much so that one may argue that the Land Act was passed in order to force large sectors of the population to become wage labourers in the areas of agriculture and mining. ${ }^{16}$ By contrast, since 1970 a vast over-supply of unskilled labour and a shortage of highly skilled labour in the service sector have emerged, due to structural shifts in production. ${ }^{17}$ This has led to the problem of structural unemployment that is exacerbated by urbanisation and population growth. Such surplus population can no longer be exported to colonies or land lying fallow somewhere else. ${ }^{18}$

The significance of the land question in urban areas should therefore not be underestimated, especially amongst those people who no longer have access to an independent means of subsistence but who are also not engaged in formal wage labour. The central issue for urban people seems to be job creation, not land reform. However, given high levels of unemployment, the occupation of urban land becomes again central in the form of housing, land occupation for informal settlements, sanitation and other forms of service delivery. The unemployed reside in informal settlements and adopt various survival strategies. As Hendricks, Ntzebeza and Helliker observe, there is a need to recognise the plight of those who reside outside the binaries of rural peasantry and urban proletariat. Shack settlements have become the primary site for popular protest. Homelessness in urban areas mirrors the landlessness of rural areas:

Their struggles are not contained by the discipline of urban labour, and the response of the state [government] to their existence has ranged from denial to open hostility ... It is clear that this group of people forms part of a surplus working population, or an industrial reserve army of labour, yet the sheer scale of unemployment suggests that in South Africa something more profound is currently afoot... Just like the generalised impasse that exists for land reform in the rural area, the official response by contemporary authorities to the urban demand for housing has been one of inertia, neglect or intimidation. Since people have been left to fend for themselves, shack settlements have mushroomed all over the country and the question of dealing with this unplanned urbanisation is a major issue for local governments. However, it is not that the state [government] has done nothing at all: since 1994 many houses have in fact been built throughout the country, but the backlog nonetheless keeps growing. ${ }^{19}$

15 The most detailed (albeit contested) discussion of inequality in South Africa (with specific reference to labour relations) remains Sampie Terreblanche's, A History of Inequality in South Africa 1652-2002. Scottsville: UKZN Press, 2002. See also his Lost in transformation. Sandton: KMM Review, 2012. There is a wealth of other econometric studies on economic inequalities in South Africa, including the Diagnostic Overview released by the National Planning Commission in 2011:8ff, but to provide a survey and assessment of such literature lies beyond my competence.

16 See Terreblanche, A History of Inequality, p. 260-264.

17 See Terreblanche, A History of Inequality, p. 378. Terreblanche's argument is that since 1970 there has been an overinvestment in capital-intensive economic activities and an under-investment in labour-intensive activities. As a result, a growing number of the mostly African proletariat became unemployed. This was aggravated by sluggish economic growth since 1970, combined with sustained population growth.

18 See Hendricks, "Rhetoric and reality in restitution and redistribution", p. 45.

19 Hendricks, Ntsebeza and Helliker, The Promise of Land, p. 4. 
Given these observations it seems clear that the ecological dimension of land reform is of an urban and not only a rural nature. I suggest that the emergence of 'poo protesting' may help us to see the ecological dimension of inequality and the direction which urban land reform should take.

\section{Observations on the Ecological Dimension of 'Poo Protesting'}

Popular opinion suggests that poverty and stark economic inequalities cannot but undermine social stability. But why have protests over service delivery erupted and become so widespread within the last few years? In this section I will offer some observations in this regard, derived mainly from media reports in this regard, with the obvious limitations that such sources entail. ${ }^{20}$

Several factors are clearly involved. Some may focus on the depleted administrative and technical competence as a result of affirmative action policies (and nepotism) in making appointments in municipalities across the country. Others would refer to rising expectations fuelled by the vulgar display of wealth amongst the new elite. In his state of the nation address (13 February 2014) President Jacob Zuma suggested that it is not the failure but the success of service delivery that leads to rising expectations where such services are not yet available. ${ }^{21}$ I suspect that such protests are not about service delivery in the first place but by a lack of housing, frustrations over unemployment and the intuitive recognition that inadequate education translates into long-term unemployability. The root causes of service delivery protests are related to abject living conditions and the capability to organise dissent - and not so much unrealistic expectations or consumerist aspirations. ${ }^{22}$ The issues are well-known and need no comment here: the location of housing (e.g. land vulnerable to flooding, traffic, trains and noise pollution), the size and quality of housing, ${ }^{23}$ access to

20 A respondent to an earlier version of this contribution informed me that the literature on the causes of social instability tend to focus either on factors (grievances) that raise the preference for rebellion (as emphasised by social scientists) or the economic constraints on the ability to organise such rebellion (as emphasised by economists). There is a body of literature here that would need to be consulted in order to address the causes of social instability in more depth. See, for example, P Collier \& AA Hoeffler, "Greed and Grievance in Civil War", Oxford Economic Papers 56:4 (2004:563-595); and J Esteban \& G Schneider, "Polarization and Conflict: Theoretical and empirical issues", Journal of Peace Research 45:2 (2008:131-141).

21 There is some intuitive wisdom behind this remark: If $92 \%$ of people now have access to potable water, the expectation and anger of the remaining $8 \%$ will rise. However, this does not address the needs of around $40 \%$ of the population that still live in abject poverty. In an article on the reasons behind service delivery protests Jeremy Cronin comments that the epicentre of such protests are typically in contexts of relative deprivation where people are worse off in terms of housing, electricity and sanitation than in neighbouring wards. The problem is therefore the unevenness and not the absence of services. Cronin adds that the deeper, more insidious roots of the protests are related to the way in which such services are provided, namely by way of municipal tendering. With limited budgets, adaptations in the rates base and soaring demands the real power of municipal councils lie in the awarding of such tenders. It is therefore not surprising that in several cases such protests are fuelled by former councillors and out of favour local businessmen belonging to competing ANC factions. He concludes that it is "not so much the absence of services but desperate competition over who controls their allocation that triggers protest." Participatory and transparent decision making processes in municipal service delivery are therefore needed. See Cape Times, 26 February 2014:11.

22 I have argued elsewhere that consumerism not only exacerbates economic inequalities and undermines social stability, but is also the driving force behind an expanding environmental and carbon footprint. Inversely, economic inequalities fuel consumerism because the affluent seek to imitate the super-rich and to differentiate themselves from the poor, while the lifestyles of the affluent prompt the upward social mobility of the lower-middle class. Both the lifestyles of the affluent and the poor have a destructive environmental impact, albeit in very different ways. See my Christianity and the Critique of Consumerism (Wellington: Bible Media, 2009). 
potable water, access to electricity, adequate sanitation, fire precautions ${ }^{24}$ and services and waste removal. All of these are clearly ecological in nature. The economic, social and psychological impact of such living conditions is exacerbated by the many traps associated with endemic poverty: gangsterism, crime, alcohol and drug abuse, prostitution and gambling.

The most graphic illustration of inadequate service delivery is surely sanitation. The problem is simple and immediate: it stinks! At an experiential level the bad odour hanging in the air serves as a constant reminder of what a life lived in poverty actually entails. The lack of sanitation, probably more than anything else, fuels anger (given an awareness of unequal access to adequate sanitation), frustration and the desire for improved living conditions. The recent report on water and sanitation released by the South African Human Rights Commission includes the following graphic findings on the scope of the problem:

- Approximately 11\% (1.4 million) of households (formal and informal) still have to be provided with sanitation services (these households have never had a government supported sanitation intervention);

- At least $26 \%$ (3.8 million) of households within formal areas have sanitation services which do not meet the required standards due to the deterioration of infrastructure caused by lack of technical capacity to ensure effective operation, timeous maintenance, refurbishment and/or upgrading, pit emptying services and/or insufficient water resources.

- Although the un-served population is $11 \%$ of the national total, their predominance is in the widely dispersed rural settlements of KwaZulu-Natal, North West and the Eastern Cape. The areas with high levels of infrastructure maintenance needs are located within Limpopo, KwaZulu-Natal, Free State, Mpumalanga, Northern Cape and the Eastern Cape.

- Based on an assessment of the provision of water services, 23 municipalities (9\% of the total) were in a crisis state, with an acute risk of disease outbreak; and

- A further $38 \%$ were at high risk, with the potential to deteriorate into a state of crisis. $^{25}$

settlements), the city's housing needs database has approximately 275000 registered housing applicants. At the present rate of delivery of social housing the backlog is increasing. She adds that land invasion of state owned land and private land hinders planned service delivery and undermines fairness by 'jumping the queue'. The problem is partly that the city may not provide basic services on privately owned land occupied tacitly or illegally through informal settlement since that would amount to the use of public funds to improve private property. See her article "Land invasions just hinder the city's planned service delivery", Cape Times 25 February 2014:9. A study conducted in 2005 found that about a quarter of Cape Town's population (450 000 people) live in shacks with more arriving every day. Moreover, competing claims over land have become deeply racialised: "After centuries of separation and differential treatment, the difficulties of imagining a unitary South African nation are aggravated by the everincreasing layers of competing claims over land. See Hendricks, Ntsebeza and Helliker, The Promise of Land, p. 6, 8. Hendricks and Pithouse observe that the post-apartheid state has built more than 2.5 million houses since 1994 but many residents of these houses have experienced them as profoundly inadequate in size, quality and location. They are smaller and more poorly constructed than the township housing built under apartheid and are often further from the cities than townships built under apartheid. See Fred Hendricks and Richard Pithouse, "Urban land questions in contemporary South Africa: The case of Cape Town", in Hendricks, Ntsebeza and Helliker, The Promise of Land, p. 116.

24 See Stephen Lamb's article entitled 'Designs against shack fires', Cape Times, 6 January 2014:9. He suggests that there are simple, affordable and low-tech ways of preventing the spread of flames even in wind-driven conditions through pre-emptive re-organisation of informal settlement structures that are fireproof and insulated.

25 See the report entitled "Water and Sanitation, Life and Dignity: Accountability to People who are Poor", p. 13 (quoted verbatim). See C:/Users/user/Downloads/report_right_access_water_sanitation2014_a.pdf. 
There is even more to it than that. As Steven Robbins remarks, the issue of sanitation may well be the root incentive behind policies of segregation and later apartheid:

The history of sanitation in South Africa has been narrated as a story of how colonial discourses on hygiene and infectious disease contributed towards the making of racially segregated cities. It was the proximity of the human waste of the poor to white colonial elites that was perceived to be a threat to public health and urban social order. ${ }^{26}$

At a superficial level sanitation is a matter of municipal service delivery in integrated municipalities. ${ }^{27}$ However, it is much more complicated than that as indicated by the following observations with regard to the Cape Flats. Sanitation options range from open sewage, the bucket system, ${ }^{28}$ compost toilets, chemical toilets to water-based flush toilets. ${ }^{29}$ The demand for service delivery in this area is to introduce flush toilets. However, there are two ecological problems here. The one is that such a system could aggravate the predicted chronic water shortages in the Western Cape. Given the use of such water for farming and lush gardens, there are serious issues of justice and pricing to be addressed. The other is that several areas with informal settlements are simply not suitable for flush toilets because the water table is too high. ${ }^{30}$

All of this is rather ironic because the ecological value of sewage is undeniable. It is not something that we merely need to get rid of. It is amazing that we flush away a resource that is so valuable in terms of compost and in the process contaminate precious fresh water supplies. That there is a problem is a function of population density in urban areas. The management of sewage systems has indeed been a crucial aspect of urbanisation since the rise of the earliest civilisations. ${ }^{31}$ Where water systems become systemically polluted, that leads to the spread of water-borne diseases such as cholera. ${ }^{32}$ Accordingly, the challenge for service delivery is to develop, maintain and expand infrastructure for water supply and wastewater treatment. ${ }^{33}$ However, the problem is not the poo but its proper distribution and

26 See Steven Robbins, "The history and politics of poo", Cape Times, 7 January 2014:9. He concludes that the stench from urban slums may eventually force bureaucrats and middle-class citizens to recognise their complicity in the lives of those trapped in abject poverty.

27 See also Antjie Krog's perceptive reflections on the integration of township and town sewage systems in Kroonstad in A Change of Tongue. Johannesburg: Random House, 2003:354-358.

28 It was reported that Human Settlements Minister Connie September vouched to eradicate the use of bucket toilets by the end of March 2014. This was in response to the report by the SA Human Rights commission on access to water and sanitation. See Cape Times, 12 March 2014:7. See also her article "Time to flush out evil legacy", Cape Times, 24 March 2014:11. She comments that "The bucket system is the unwanted legacy of deliberate neglect. Daily the users of this unhygienic sanitation system as well as workers responsible for the collection and disposal of human waste from bucket toilet are subjected to dehumanisation and unhygienic conditions."

29 This is not to mention the infamous 'flying toilets' used in Nairobi where waste in plastic bags are thrown to the nearest roof or path. Apparently this system is also in use in Khayamandi, within a few kilometres from where I live.

30 According to Paul Hoffman (the Director of the Institute for Accountability and a member of the Concerned Citizens Group), $82 \%$ of informal settlers in Cape Town live on land that cannot be developed by the city for one reason or another. See Cape Times, 11 February 2014:9.

31 For a discussion, see Jodi Magness, "What's the poop on ancient toilets and toilet habits?", Near Eastern Archaeology, 75:2 (2012:80-87). Some cities had sewerage systems with running water. In others the contents of chamber pots were emptied in the streets or in cesspits. Manure merchants who were paid to clean cesspits sold the contents as fertilizer ('night soil') for agricultural fields.

32 See the posthumous article by Steve de Gruchy on cholera, entitled "Water and Spirit: Theology in the time of cholera", The Ecumenical Review 62:2 (2010:188-201).

33 Connie September acknowledges that an integrated approach is necessary where infrastructure development and maintenance are combined with environmental sustainability, community involvement, affordability, and user education. She notes: "Part of the challenge facing the programme is the development of bulk water and wastewater 
integration in ecosystems. We may all agree that its proper place is not the entrance to Cape Town International Airport. ${ }^{34}$ Neither is it river systems or poo rivulets in our townships. ${ }^{35}$ What, then, is its proper place in urban landscapes? Could it be used as compost for vegetable gardens in urban farming ? $^{36}$

The current problem in Cape Town is clearly aggravated by the influx of people and the rapid expansion of the city. ${ }^{37}$ There is such a backlog of housing that it is unlikely that the problem will be resolved anytime soon. ${ }^{38}$ In addition, the Anti-Land Invasion Unit (established in Cape Town in 2008) seeks to prevent or remove unauthorised housing structures that have recently been erected on municipal land. It does this on the basis of the Prevention of Illegal Eviction from and Unlawful Occupation of Land Act (no 19) of 1998. It has been very 'successful' in this regard, reportedly demolishing 400 to 500 shacks per month. As Hendricks, Ntzebeza and Helliker observe, "In many ways the recent forced removals represent continuities with the apartheid past, rather than a rupture in the democratic transition. The implied assumption of the current policy is that the homes of shack dwellers will eventually give away to formal housing, however very few practical plans for realising this have been put in place." 39

Nevertheless, the majority of Cape Town's households have access to basic services, even though they live in shacks. Housing provision is therefore lagging behind service provision. As Mark Swilling observes: "This has a lot to do with the fact that infrastructure service planning and funding is a municipal responsibility, while financing for housing construction is a provincial government responsibility financed from subsidies provided by national government."40

treatment infrastructure where none exist, and the increase in capacity where infrastructure does exist but has not held pace with the growth of water borne sanitation." See Cape Times, 24 March 2014:11.

34 Jeremy Cronin may wish to differ. He notes that there is no longer an appalling odour in the concourse of the airport but it's still there in many parts of Khayelitsha. In his opinion the strategy behind the poo protests is not entirely wrong: "It was an attempt to carry anger and protest out of the confines of the informal settlement ... this was an attempt to raise wider questions. Why are the resources of our city not shared more equitably? Why should we take pride in Cape Town being World Design Capital 2014 when so many of us are forced to live in the most squalid circumstances?" See his article "Human waste - and informal settlements' fight for dignity", Cape Times, 12 March 2014.

35 See the opinion piece by Paul Hoffman entitled "Truly accommodating homes: Cheap 'light houses' a humane solution”, Cape Times, 25 March 2014:9. Hofmann describes a creative affordable housing design for informal settlements that includes a 'vertical' vegetable garden, compost toilets and chicken coop.

36 Andile Lili, one of the leaders of the poo protestors, is reported to have said after the protest at Cape Town International Airport: "We wanted them to know that our people have been living with uncleaned toilets that are filled up for three months. The so-called environmentalists don't say anything about the health risks the people in townships are faced with daily. We want the United Nations and these so-called environmentalists to know that the city does not care about the health of black people," See the report by Xolani Koyana and Cobus Coetzee, Cape Times, 26 June 2013.

37 The mid-term review (2011-2013) of the City of Cape Town notes that the 2011 census indicates that the population of the city has grown by $30 \%$ compared to 2001 .

38 For a historical overview of contestation over land in Cape Town, see the essay by Fred Hendricks and Richard Pithouse, "Urban land questions in contemporary South Africa: the case of Cape Town", in Hendricks, Ntsebeza and Helliker, The Promise of Land, p. 103-129.

39 Hendricks, Ntsebeza and Helliker, The Promise of Land, p. 6.

40 See Mark Swilling, "Sustainability, poverty and municipal services: The case of Cape Town, South Africa", Sustainable Development 18 [2010:194-201 (196)]. See also his Sustaining Cape Town: Imagining a Liveable City. Stellenbosch SUN Press, 2010. 
In such a context it comes as no surprise that sanitation has become highly politicised. The DA municipal government is accused of inadequate service delivery to the poorer sections of the city, an accusation that is adamantly denied by the city council. ${ }^{41}$ It retorts that plastic (porta-potty) or chemical toilets are provided where flush toilets cannot be installed $^{42}$ but that these are vandalised by protestors who seek to make the province ungovernable and will latch onto any complaints for political gain. ${ }^{43}$ It is in this volatile political context that the phenomenon of poo protesting emerged.

Protests over service delivery in Cape Town boiled over following marches organised by the Ses'khona People's Rights Movement in October 2013. The term Ses'kona, meaning 'we're here', suggests that we are not aliens and that we demand certain rights in this city. In one incident marchers looted shops and stalls in St George's Mall causing considerable loss of property and livelihood. In other incidents Loyiso Nkohla and Andile Lili, who were both city councillors, led marches against the City of Cape Town's use of portable toilets in informal settlements and in the process dumped faeces at the entrance to the Western Cape Legislature and at Cape Town International Airport. This took service delivery protests to a new level, triggering disgust and panic amongst the middle class and amongst city officials trying to portray Cape Town as a prime tourist destination. ${ }^{44}$ As Steven Robbins observes, the poo protestors seem to demonstrate through human waste that they themselves are treated as waste products who are superfluous to the labour needs of industrialised capitalism. They break out of the zones of isolation, containment and surveillance in order to demonstrate the realities of inequality. ${ }^{45}$

Statements from such leaders and another march planned in protest against the lack of proper sanitation (threatening to wreak havoc on streets of Cape Town and to empty toilet buckets at civic sites) prompted a group of 86 concerned citizens to issue a hard-hitting statement in November 2013 expressing their concerns over the state of democracy in the province evidenced by violent and destructive protest action and threats and "blatant attempts to make the province "ungovernable'." The statement was endorsed by senior religious leaders, including Archbishop Thabo Makgoba and emeritus Archbishop Desmond Tutu. ${ }^{46}$ The G86 (as it became subsequently known) also expressed concern over

41 According to the impressive mid-term review (2011-2013) of the City of Cape Town, the National Department of Water Affairs recognised that $100 \%$ of the citizens of Cape Town have access to adequate sanitation in informal housing areas. It also claims that the city has the best record of any metro in the country in terms of providing basic services and providing financial relief to the poor. The budget for direct service delivery to informal settlements has increased from R249 million in 2006/2007 to close to R1 billion. The budget for sanitation in informal settlements has increased from R123 million in 2006 to R521 million in 2014. The number of toilets provided in informal settlements (including 1100 flush toilets and 7400 portable flush toilets since April 2013) has increased from 14591 in 2006 to around 40 770. In addition a unique janitorial service programme (employing some 800 janitors) is introduced to clean toilets in informal settlements on a regular basis.

42 The mid-term review (2011-2013) of the City of Cape Town states that "Portable flush toilets are a hygienic, safe and dignified sanitation option that is made available over and above other sanitation provision. They are serviced up to three times a week. The City makes them available on a completely voluntary basis, and they have been generally well received." (p. 23).

43 According to Ernest Sonnenberg Cape Town spent R13 million on repairing vandalised toilets in a period of six months in informal settlements. See the report in the Cape Times, 16 January 2014, p. 1. See also the controversy over stolen porta-potty toilets used for poo protests, http://www.iol.co.za/news/crime-courts/stolen-toilets-used-inpoo-protests-1.1562988\#.Ux_u9vmSySo (25 August 2013).

44 See Steven Robbins, “The history and politics of poo", Cape Times, 7 January 2014:9.

45 See Steven Robbins, "The history and politics of poo", Cape Times, 7 January 2014:9, almost verbatim. See also the response in a letter to the editor by Paul Boughey, Cape Times, 8 January 2014:8. 
service delivery, housing backlogs and living conditions. ${ }^{47}$ Some members of the group then participated in a 'walk of witness' in Khayelitsha to ensure a shared understanding of living conditions there. ${ }^{48}$ Individual members of the group offered assistance to resolve problems around the acquisition of land for housing (notably the former military bases at Wingfield and Youngsfield owned by the national government) and to solicit funding for such housing. This led to a series of bilateral meetings between representatives of this group of concerned citizens, of the so-called poo protestors and of the city council, including a meeting with the mayor of Cape Town and premier of the Western Cape Province on 9 January 2014. ${ }^{49}$ Such initiatives managed to prevent other planned marches on the basis of undertakings to mediate between the protestors and the city council. However, such mediation efforts were eventually rejected by the protestors as fruitless ${ }^{50}$ and by city councillors as ill-informed and naïve (given deliberate political attempts to make the city 'ungovernable'). ${ }^{51}$ Another (illegal) march subsequently took place on 27

47 The opening two paragraphs of this statement (released on 26 November 2013) reads: "The delivery of services to the poor in this Province and across the country is inadequate, and it is understandable that poor people are feeling frustrated and angry. Everything must be done to get rid of bottlenecks and improve the service delivery situation here and across the country. However constructive engagement on the best way forward is possible and desirable, without resort to violence, and without fomenting hate or disrespect. As South African citizens we are deeply concerned at the many incidents that display a complete lack of respect for true democratic values in several parts of the country. The recent examples on display in the Western Cape may be a disturbing trend that demonstrates a growing assault on democracy country wide."

48 The following press statement was released after this walk of witness: "At a meeting held on Wednesday, 4 December 2013 at Bishopscourt, chaired by Archbishop Thabo Makgoba, representatives of the 86 signatories of the Call For Action, together with the Western Cape Inter-Faith Religious Leaders Forum and of SESIKHONA (peoples' rights movement - the newly named broad representative forum of the protest network) agreed to work closely in constructive engagement with each other and various levels of government to seek and realise urgent solutions to the dehumanising realities affecting many of our poor communities on the Cape Flats". Jeremy Cronin reports that a similar walk-about found stinking cesspools, sewage bubbling out of man-holes (from formal houses that had water-borne sanitation) and a stack of 200 or so empty porta-potty containers. They were not clean but had been emptied by the council and returned for collection. See Cape Times, 12 March 2014:9.

49 A trilateral meeting including the Western Cape MEC for housing, the mayor of Cape Town, religious leaders and representatives of Ses'khona took place on 5 February. See the article by Paul Hoffman entitled "Face-to-face opportunity lost", Cape Times, 11 February 2014:9. See also the critical response to this article by George Ellis (in a letter to the editor), Cape Times 17 February 2014. He found the meeting more positive given the undertaking by the mayor to meet with Ses'khona area by area to resolve issues around vacant land.

50 According to a front page report by Jason Felix entitled "Poopetrators' sanitation protest to go ahead without city's religious leaders" in the Cape Times, 24 January 2014:1, leaders of the Cape Town Informal Settlements Group distanced themselves from the Western Cape Religious Leaders Forum and the Concerned Citizens Group since they failed to arrange meetings with premier Helen Zille to discussion sanitation issues. The report states that Andile Lili was disappointed with the report back from the religious leaders: "We will use stones, potti potti's and everything else we have to protest in the city. We will make this city ungovernable. We are not going to be aligned with the religious leaders anymore." Nkohla added: "The religious leaders proposed a march for both sanitation and to honour Madiba. We don't want that." John de Gruchy comments: "The leaders of the protest and undoubtedly many of their followers, including some in the churches, were suspicious of the motives of what appeared to be a bunch of wellintentioned but naive, largely white professional types and clergy who were regarded by some as simply neo-liberal reactionaries associated with the Democratic Alliance. Were we, in short, not simply getting in the way of the revolution to bring about real change." See his A Theological Odyssey: My Life in Writing. Stellenbosch, SUN Press, 2014:173.

51 In a rather scathing letter to the editor (Cape Times, 13 February 2014:12) Paul Boughey, the Chief of Staff, Office of the Executive Mayor of Cape Town, commented that the facilitation efforts of the Concerned Citizens Group amounted to a 'farce': "They were singularly unable to control this interaction, and instead allowed Ses'khona to insult, defame and threaten." He added: "It takes a special kind of arrogance to believe that a group of out-of-touch individuals can simply apply a Midas touch and resolve complex issues of delivery with no understanding of what this actually entails. If the meeting of 5 February illustrated anything, it is that often the best of intentions, without proper thought, can end up doing more harm than good." 
February 2014, following unsuccessful meetings between the Ses'khona People's Rights Movement and the Mayor of Cape Town. ${ }^{52}$ In the interim Nkohla was removed as a Councillor of the City of Cape Town (29 January 2014). Nkohla was also expelled from the ANC, while Lili was suspended for one year - for organising such marches without authorisation from the ANC's regional leaders and for bringing the party into disrepute by dumping faeces at the legislature building and the airport. ${ }^{53}$ Both were subsequently reinstated as ANC members following an appeal.

The apparently failed attempt by religious leaders (most of whom are Christians) to offer mediation in the conflict over service delivery begs some deeper theological questions. At least the voice of the church was heard in this situation, but it is far from clear what stand the church should take. Should the emphasis be on calling for an inclusive and participatory democracy? Or on the need for good governance and service delivery? Or on policy making to ensure a pro poor budget? Or on soliciting funding from the corporate world? Or should the church be seen as standing in solidarity with protests over service delivery? Also if such protests are politically motivated? Also if dumping faeces is involved? Or should the church seek a mediating role, not taking sides but ensuring better communication? In each case such a stance would indicate a particular alignment with economic and political constellations of power. It is tempting to invite the analogy of the varied relationships that Jesus of Nazareth had with the Sadducees, the Pharisees, the Zealots (surely that is where the poo protestors would be found!) and the Essenes. But there are also deeper theological questions that have to be addressed.

\section{Theological (and indeed Trinitarian) Reflections on Sanitation}

In order to focus on the ecological dimension of this debate I will offer some theological and ethical reflections on the issue of sanitation since this seems to be at the heart of the debate on land use and is implied in the allocation of land for housing and in the (legal or illegal) selection of land for informal settlements. There is very little ethical or theological reflection on sanitation in South African literature. ${ }^{54}$ Whatever reflection there may be would be related, quite appropriately, with issues of human dignity, health, privacy and safety (especially for women and girls). ${ }^{55}$ However, such sanitation is often interpreted in the context of a form of civilisation characterised by the use of flush toilets. This may well be expressed in a Victorian morale where any talk about poo is nothing but bad taste if not

52 See Sunday Argus, 2 March 2014, p. 1, 6.

53 See Cobus Coetzee's report, “ANC expels poo protestor Loyiso Nkohla”, Cape Times, 25 February 2014:1,4.

According to this report ANC spokesperson André Gaum said that the ANC agreed that the sanitary conditions under which communities live are 'unacceptable and indefensible'.

54 One exception is the article on cholera by Steve de Gruchy mentioned above. He also delivered a plenary address to the Third World Forum on Theology and Liberation (Belém, Brazil, 2009) that he referred to as 'shit theology' published as "Dealing with our own sewage: Spirituality and ethics in the sustainability agenda", Journal of Theology for Southern Africa 134 (July 2009:53-65). See also the epilogue in his father John de Gruchy's A Theological Odyssey, pp. 167-179. This epilogue includes sections on "Doing theology in Dialogue with Steve" and on "Poo protests and Olive Theology: The Church as Agent of Peace". John de Gruchy was also a member of the Concerned Citizens Group. The essay, like the present contribution, engages critically with the approach adopted by the Concerned Citizens Group.

55 For such an emphasis on human dignity, see the report on water and sanitation, entitled "Water and Sanitation, Life and Dignity: Accountability to People who are Poor", released by the South African Human Rights Commission (11 March 2014). See http://www.sahrc.org.za. 
bad humour. The ecological dimension of sanitation is hardly in sight (not to mention within smelling distance).

In the biblical roots of the Christian tradition one finds health regulations (e.g. Deut 23:9-14) that include aspects of sanitation based on the distinction between what is pure and impure. ${ }^{56}$ There is even some toilet humour in the story about Ehud (Judges 3:24). Jesus challenged the dominant understanding of purity. He apparently did not consider excrement (that is, what passes through the stomach and into the sewer) to be impure. According to the gospel of Mark (7:17-23) he said: "Do you not see that whatever goes into a person from outside cannot defile, since it enters, not the heart, but the stomach, and goes out into the sewer? (Thus he declared all foods clean.) ... It is what comes out from a person that defiles ... For it is from within, from the human heart, that evil intentions come ... All these evil things come from within, and they defile a person" (NRSV). ${ }^{57}$

One may be tempted to think that there is nothing more to it than that ${ }^{58}$ That would underestimate the spectre of docetism though. In Christological debates on docetism the question was raised whether Jesus had intestines. To say that God incarnate had intestines (requiring urination and defecation) was unthinkable for Greek sensibilities. Pneumatological docetism easily followed suit on the basis of the distinction between spirit and matter, between the seen and the unseen, between what has lasting and what has passing (!) value. Similar debates raged over the hope for the resurrection of the body. It was dismissed by Gnostic critics as nothing but a hope for worms. ${ }^{59}$ Wherever ecclesiological docetism appears, the church tends to position itself on the side of a civilised, well-educated elite assuming comfortable living conditions with adequate sanitation. ${ }^{60}$ If Christian beliefs may be criticised by the cultured despisers of religion, docetic Christianity may well find itself on the side of the cultured despisers of shit.

The stark challenge to gnostic forms of Christianity may be illustrated by two instances where theological protests over poo are discussed in non-theological literature.

In his novel The unbearable lightness of being Milan Kundera reflects on an incident in which Yakov, the son of Stalin, died in a Nazi concentration camp after being captured by the Germans. He was not willing to help clean latrines that he shared with British officers and was apparently so upset by their complaints and the implied humiliation that he

56 See Magness, "What's the poop on ancient toilets and toilet habits?", p. 84f. She observes that "The legislation in Deuteronomy 23:9-14 implies that excrement is indecent and must be kept hidden from God's view, but it does not state that excrement is impure." Human excrement was widely used as fuel. In fact, in Rabbinic Judaism (unlike in the Qumran community) defecation is associated with purity instead of impurity because its evacuation renders the body clean.

57 See Magness, "What's the poop on ancient toilets and toilet habits?", p. 86.

58 The large database of the American Theological Library Association has 8 entries on sanitation. Two are on hygiene in general, three are on Islam, one on archaeology in ancient Israel (see Magness above), one is in Spanish and one is on church history. For the last mentioned, see Bernard Aspinwall, "Social Catholicism and health: Dr and Mrs Thomas Low Nichols in Britain”, in WJ Shells (ed.): Church and Healing. Oxford : Basil Blackwell, 1982:249-270. Other searches may need to be done since this probably does not reflect earlier theological literature, including contributions by classic authors such as John Wesley and John Calvin who were not oblivious to issues of health and sanitation.

59 See Brian E Daley, “A hope for worms: Early Christian hope”, in: Ted Peters, Robert John Russell \& Michael Welker (eds.): Resurrection: Theological and Scientific Assessments. Grand Rapids: WB Eerdmans, 2002:136-164.

60 By contrast, one may mention the uninhibited scatological language employed by Martin Luther. For a discussion, see Carl P.E. Springer, "Luther's Latin Poetry and Scatology", Lutheran Quarterly 23

(2009:373-386). 
committed suicide by running into the electrified fences. ${ }^{61}$ The available evidence suggests that Yakov's father killed the woman by whom he had the son. Kundera notes that "Young Stalin was therefore both the Son of God (because his father was revered like God) and His cast-off." ${ }^{\prime \prime 2}$ He resented being judged not for something sublime (as a fallen angel and the Son of God) but for nothing but shit. Kundera adds: “... if there is no difference between the sublime and the paltry, if the Son of God can undergo judgment for shit, then human existence loses its dimensions and become unbearably light." ${ }^{63}$ However, if Stalin's son laid down his life for shit, that may be less senseless than the deaths of Germans and Russians who sacrificed their lives to extend their countries' power to the east or the west: "Amid the general idiocy of war, the death of Stalin's son stands out as the sole metaphysical death."64

On this basis Kundera offers some theological reflections on the question whether God has intestines if God indeed has a mouth (and presumably eats). He finds that repulsive but that begs the question whether humans (who have intestines) are really created in God's image. He quotes the Gnostic master Valentinus who resolved the damnable dilemma by claiming that Jesus ate and drank but did not defecate ${ }^{65}$ Kundera's own observation is that shit is a more onerous problem than evil (which can be explained with reference to freedom): the responsibility for shit rests entirely with the Creator. On this basis he presumes that humans were not repelled by defecation in paradise but only experienced disgust and shame after being expelled from paradise. This begs the question of a categorical agreement with being associated with the affirmation of creation in Genesis. Why, then, is there an objection to shit? This objection is not a moral but a metaphysical one: "The daily defecation session is daily proof of the unacceptability of creation. Either/or: either shit is acceptable (in which case don't lock yourself in the bathroom!) or we are created in an unacceptable manner." ${ }^{\prime 66}$ Kundera concludes: "the aesthetic ideal of the categorical agreement with being is a world in which shit is denied and everyone acts as though it did not exist. This aesthetic ideal is called kitsch... Kitsch is the absolute denial of shit, in both the literal and the figurative senses of the word: kitsch excludes everything from its purview which is essentially unacceptable in human existence.",67

Another reflection on poo is found in a chapter entitled "You should give a shit!" in Slavoj Žižek's book On Belief. The book is an extended, outrageous commentary on Gnosticism in a digital age of 'virtual reality' in which Žižek raises the question: "Is it that Christ had to sacrifice himself for the sins of His Father who created such an imperfect world?" 68 Or worse: the visible, tangible world may be in its entirety a diabolical phenomenon. Accordingly, Christ dies in order to redeem his father in the eyes of humanity? ${ }^{69}$

61 One is tempted to ask what would Jesus have done in Stalin's son's position! This unwillingness to be involved in cleaning toilets is vividly illustrated by an incident in the life of Ghandi where he urged his wife to help clean toilets a job reserved for Dalits only. One is also reminded of Jean Valjean's heroic deed in Victor Hugo's Les Misérables to carry the body of Marius (Cosette's beloved) through the sewers of Paris.

See Milan Kundera, The Unbearable Lightness of Being. London and Boston: Faber and Faber, 1985:244.

63 Kundera, The Unbearable Lightness of Being, p. 244.

64 Kundera, The Unbearable Lightness of Being, p. 245.

65 Kundera, The Unbearable Lightness of Being, p. 246.

66 Kundera, The Unbearable Lightness of Being, p. 248.

67 See Kundera, The Unbearable Lightness of Being, p. 248.

68 See Slavoj Žižek, On Belief. London: Routledge, 2001:6.

69 Žižek, On Belief, p. 7. Žižek argues that Christianity implies a desublimation of the emphasis in Judaism on God as the transcendent, sublime Other. God is not reduced to the human; the incarnation implies the descending of the 
Drawing on Freud (who regards excrement as the primordial gift of an infant to parents) and Lacan, Žižek notes that one of the features that distinguishes humans from other animals is that the disposal of shit becomes a problem for humans: "not because it has a bad smell, but because it came out from our innermost selves. We are ashamed of shit because, in it, we expose/externalise our innermost intimacy. Animals do not have a problem with it because they do not have an 'interior' like humans... It comes from inside the body, and this inside is evil, criminal.",70

He draws on a scene from Bunuel's Le Fantôme de la liberté where the relation between eating and defecating is reversed. People sit at their toilets around the table talking pleasantly and when one of them wants to eat silently asks the housekeeper "Where is that place, you know?" and sneaks to a small room at the back. ${ }^{71}$ On this basis he inverses the comment: "True, man is an animal who does detestable things like excreting shit, but we should not forget that he nonetheless does noble things, like elevating the act of eating (which produced shit) into a sublime social ritual" by saying: "True, man does really enjoyable things like relieving himself in the toilet, but nonetheless, we should not forget that he has to pay for this by the boring civilized ritual of eating.,"72

In response to such observations, one may argue that Christianity is the most materialist of all religions, given its emphasis on God's good creation, on the incarnation, on the indwelling of the Spirit, and the hope for the resurrection of the dead. One may say that the use of bread and wine necessarily requires sanitation and the water of baptism are surely relevant for such sanitation too. Note that a double need for sanitation is implied here. It is both necessary as a result of an affirmation of what is bodily, earthly and material and because of a need for health, purification and dignity. The need for sanitation should not be associated with the shadow side of creation, or (even worse) with human sin. Accordingly, Christians need to interpret issues around sanitation in terms of God's acts both of creation and of salvation. ${ }^{73}$ Without an affirmation of creation, human faeces would be regarded as a problem that has to be excised at best through flush toilets if not through God's forgiveness. Without the transforming impact of the gospel, human faeces will undermine hygiene and will not be recycled to play a beneficial ecological role as compost.

\section{Concluding Comments}

How may such theological reflections help churches and their leaders to relate to poo protesting? Why is that the cause of poo protestors is taken up (at least in the Cape Times) by Jeremy Cronin, the deputy minister of public works and also the deputy general secretary of the South African Communist Party (see above)? What distinctly religious

sublime Beyond to the everyday: "Christ is a 'ready-made' God, ... he is fully human, inherently indistinguishable from other humans ...” Transcendence is not abolished, but made accessible. See Žižek, On Belief, p. 90. indeed what comes from the inside that defiles. The difference of opinion is on the question whether the problem lies with the stomach (Žižek albeit in jest) or with the human heart (Jesus as reported in the Gospel according to Mark). Indeed, in Roman times communal latrines served as an opportunity for socialising. See Magness, "What's the poop on ancient toilets and toilet habits?", p. 80.

72 Žižek, On Belief, p. 60.

73 See the three volumes on this theme that recently appeared from LIT Verlag in Berlin in its series Studies in Religion and the Environment: Ernst M. Conradie (ed.), Creation and Salvation, Volume 1: A Mosaic of Essays on Selected Classic Christian Theologians (2011); Ernst M. Conradie (ed.), Creation and Salvation, Volume 2: A Companion on Recent Theological Movements (2012) and Ernst M Conradie, Saving the Earth? The Legacy of Reformed views on 'Re-creation' (2013). 
contribution has the G86 made to help the City of Cape Town to address service delivery? And how may such theological reflections contribute to wider debates on land reform and land redistribution? How would this strengthen the struggle for housing, adequate sanitation and dignity? Can this help all of us to appreciate the proper place of poo in the ecosystem?

I cannot answer such questions, but I do think that we need to learn to see poo as part of God's good creation. We need systems of sanitation, especially on the Cape Flats, that can see the ecological value of human faeces and can reintegrate such compost into the ecosystems. But more importantly, Christians need to see heavily degraded urban areas as part of God's beloved creation too. We need to insist that the healing power of the gospel be brought to bear to the ecological transformation of such land. The focus cannot be only on future prospects for housing; it should also be on making present living conditions more bearable. Every place belongs to God; every day is precious in God's eyes.

Our sensibilities should not be shocked by the presence of poo but by the inequalities of living conditions, for example in Cape Town. The real problem with poo protesting is that faeces are dumped and not properly recycled. That is symptomatic of a deeper problem that is closely related to the ecological dimension of land reform - not only amongst shack dwellers but also of sewage systems in suburban areas. This is what the poo protestors seem to be demonstrating, quite graphically, to everyone who has eyes to see, ears to hear and noses to smell. 